\title{
World Journal of Emergency

\section{Nasoendotracheal tube obstruction by a nasal polyp in emergency oral surgery: a case report} Tatjana Goranovic*1, Morena Milic ${ }^{2}$ and Predrag Knezevic ${ }^{3}$

\author{
Address: ${ }^{1}$ Sveti Duh General Hospital, Department of Anaesthesia and ICU, Zagreb, Croatia, ${ }^{2}$ Dubrava University Hospital, Department of \\ Anaesthesiology, Reanimatology and Intensive Care Medicine, Zagreb, Croatia and ${ }^{3}$ Dubrava University Hospital, Department of Maxillofacial \\ and Oral Surgery, Zagreb, Croatia \\ Email: Tatjana Goranovic* - tanjagoranovic@hotmail.com; Morena Milic - morena.milic@du.t-com.hr; Predrag Knezevic - pknezevic@kbd.hr \\ * Corresponding author
}

Published: 22 November 2007

World Journal of Emergency Surgery 2007, 2:31 doi:10.1 I86/I749-7922-2-31

This article is available from: http://www.wjes.org/content/2/I/31

(C) 2007 Goranovic et al; licensee BioMed Central Ltd.

This is an Open Access article distributed under the terms of the Creative Commons Attribution License (http://creativecommons.org/licenses/by/2.0), which permits unrestricted use, distribution, and reproduction in any medium, provided the original work is properly cited.
Received: 14 July 2007

Accepted: 22 November 2007

\begin{abstract}
Nasal polyps can make nasoendotracheal intubation difficult. We present a case of complete obstruction of a nasoendotracheal tube by a nasal polyp during a blind nasoendotracheal intubation in emergency oral surgery.
\end{abstract}

\section{Background}

Nasoendotracheal tube obstruction during intubation may occur due to the turbinate destruction [1-7]. It is a rare but possible complication. Although minor mucosal trauma is quite frequent during nasal intubation, nasoendotracheal tube obstruction caused by nasal polyps has not been reported as often as expected. We present a case of a complete obstruction of the nasoendotracheal tube by a nasal polyp during blind nasoendotracheal intubation (BNTI) in emergency oral surgery.

\section{Case presentation}

A 38-year-old man, assessed as American Society of Anesthesiologists (ASA) grade II, was admitted to our emergency department one hour after a car crash accident. On admission, the patient was conscious but amnestic for the event. His Glasgow Coma score was 15 and he complained only of pain in the mandible. Routine examinations, including cranial radiography and chest x-ray, were performed to exclude major thoracic and head injuries. A neurosurgeon confirmed cerebral concussion without neurological deficits and cervical injury. A dental x-ray revealed an open fracture of the mandible with distorted dental occlusion. Four hours after admission, the patient was scheduled for emergency fixation of the fractured mandible.

On the preoperative anesthesiologic evaluation, the patient reported to be allergic to dust and fasting for a minimum of 5 hours. He was obese (weight $100 \mathrm{~kg}$; height $180 \mathrm{~cm}$, body mass index $30.8 \mathrm{kgm}^{-2}$ ), his dental caps were loose, but all routine laboratory findings were within normal range.

Anesthesia was induced with $2.5 \mathrm{mg}$ of midazolam, $20 \mathrm{mg}$ of etomidate, and $0.15 \mathrm{mg}$ of fentanyl, followed by 100 mg of succinylcholine after 30 seconds to facilitate the intubation. When the patient was ready to be intubated, a nasal tube (size 7.5) was smoothly inserted through the right nostril into the trachea without using any force. The right position of the tube was confirmed by direct Macintosh laryngoscopy. However, once the tube was placed in the right position, manual ventilation was impossible to perform. The tube was immediately removed and the diagnosis made on-site: a nasal polyp completely obstructed the lumen of the tube and was still partly protruding from its tip. The second attempt of nasal intubation was successfully performed through the left nostril. 
The surgery was completed without complications. The patient was admitted to the intensive care unit (ICU) for observation and extubated. The following day, he was transferred from the ICU to the Maxillofacial Ward and discharged in good condition from the hospital 7 days later.

\section{Discussion}

Intranasal deformities were reported in over two-thirds of oral surgery patients, although they had patent nostrils on clinical examination and no history of nasal obstruction [8]. The most common abnormality was a deviated nasal septum, whereas polyps as an obstructive abnormality were found in only $2 \%$ of the cases [8].

Nasal polyps are non-neoplastic masses of edematous nasal or sinus mucosa. Different causes of nasal polyps require both medical and surgical therapy [9]. Prevalence is generally reported between $1-4 \%$ with higher prevalence in patients with asthma and cystic fibrosis. According to Danish authors the overall estimated incidence of symptomatic nasal polyps was 0.627 patients per thousand per year [10].

Given that these finding refer to elective cases and that many intranasal abnormalities can even then be easily neglected if endoscopic examination is not performed, emergency situations call for extra caution. In emergency cases, a tendency to speed up the physical examination and history taking carries the risk of overlooking the history of intranasal deformities. Furthermore, in oral surgery cases, the nature and site of trauma often affect the present intranasal deformities, making the nasal intubation more difficult, although it is a preferable type of intubation in oral surgery.

Unlike the turbinate, nasal polyps are soft tissue growths and can easily be amputated during trauma. Therefore, it is possible that in our patient the nasoendotracheal tube could smoothly pass through the nasal cavity and be inserted in the trachea without the polyp impeding the passage because it was amputated. On the other had, it obstructed the tip of the tube.

\section{Conclusion}

Nasoendotracheal tube obstruction during BNTI may be caused by the nasal polyp. When carrying out emergency BNTI and relying only on patient history, anesthesiologists should be aware of this rare complication and perform manual ventilation after intubation very gently in order not to push the amputated soft tissue growth further down the trachea or bronchi.

\section{Competing interests}

The author(s) declare that they have no competing interests.

\section{Authors' contributions}

TG was the anesthesiologist in the described case and drafted the manuscript.

$\mathrm{MM}$ and PK performed the literature search and jointly wrote the manuscript.

All authors read and approved the submitted version of the manuscript.

\section{Acknowledgements}

Written consent was obtained from the patient or their relative for publication of study.

\section{References}

I. Bandy DP, Theberge DM, Richardson DD: Obstruction of nasoendotracheal tube by inferior turbinate. Anesth Prog 1991, 38:27-28.

2. Ripley JF, McAnear JT, Tilson HB: Endotracheal tube obstruction due to impaction of the inferior turbinate. J Oral Maxillofac Surg 1984, 42:687-688.

3. Politis C, Schiepers JP, Heylen R: Complete obstruction of a naso-endotracheal tube. A case report. Acta Stomatol Belg 1996, 93:13-16.

4. Anderson CE, Savignac AC: Nasoendotracheal tube obstruction secondary to inferior turbinate impaction. AANA J I991, 59:538-540.

5. Hajjar J, Baylot D, Navez ML: A rare cause of obstruction of the intubation tube. Ann Fr Anesth Reanim 1993, I 2:321-322.

6. Wiel E, Vilette B, Rahmania H: Unilateral nasal obstruction. An unusual complication of nasotracheal intubation. Ann $\mathrm{Fr}$ Anesth Reanim 1997, 16:386-388.

7. Wilkinson JA, Mathis RD, Dire DJ: Turbinate destruction-a rare complication of nasotracheal intubation. J Emerg Med 1986, 4:209-2I 2 .

8. Smith JE, Reid AP: Asymptomatic intranasal abnormalities influencing the choice of nostril for nasotracheal intubation. $\mathrm{Br}$ J Anaesth 1999, 83:882-886.

9. Bikhazi N: Contemporary management of nasal polyps. Otolaryngol Clin North Am 2004, 37:327-37.

10. Larsen K, Tos M: The estimated incidence of symptomatic nasal polyps. Acta Otolaryngol 2002, 122: 179-82.

Publish with Bio Med Central and every scientist can read your work free of charge

"BioMed Central will be the most significant development for disseminating the results of biomedical research in our lifetime. "

Sir Paul Nurse, Cancer Research UK

Your research papers will be:

- available free of charge to the entire biomedical community

- peer reviewed and published immediately upon acceptance

- cited in PubMed and archived on PubMed Central

- yours - you keep the copyright

Submit your manuscript here:

http://www.biomedcentral.com/info/publishing_adv.asp
Biomedcentral 